\title{
In-vitro studies on antioxidant and antidiabetic potential of Sesoot (Garcinia picrorrhiza Miq.) fruit ethanolic extract from Indonesia
}

\author{
Sri Utami ${ }^{* 1}$, Sonny Pamuji Laksono ${ }^{1}$, Qomariyah Romadhiyani Sachrowardi ${ }^{1}$, Dewi \\ Nurul Mustaqimah ${ }^{1}$, Susi Endrini ${ }^{1}$, Ndaru Andri Damayanti ${ }^{1}$, Said Nafik ${ }^{2}$, Betharie \\ Cendera Arrahmani ${ }^{3}$, Hanna Sari Widya Kusuma ${ }^{4}$, Wahyu Widowati ${ }^{5}$ \\ ${ }^{1}$ Faculty of Medicine, YARSI University, \\ Jl. Letjend Suprapto, Cempaka Putih, Jakarta Pusat 10510, Indonesia \\ ${ }^{2}$ Directorate General of Intellectual Property, Ministry of Law and Human Rights, \\ Jl. H.R. Rasuna Said, Kuningan, Jakarta Selatan. Indonesia \\ ${ }^{3}$ Master Program of Pharmaceutical Bioprocessing Engineering, School of Life, Sciences, \\ Technical University of Munich, Alte Akademie 8, 85354 Freising, Germany \\ ${ }^{4}$ Aretha Medika Utama, Biomolecular and Biomedical Research Center \\ Jl. Babakan Jeruk 2 No. 9, Bandung 40164, Indonesia. \\ ${ }^{5}$ Faculty of Medicine, Maranatha Christian University, \\ Jl. Prof. Drg. Surya Sumantri No. 65 Bandung 40164, Indonesia
}

Submitted: 24-02-2021

Reviewed: 24-05-2021

Accepted: 30-07-2021

\begin{abstract}
Diabetes mellitus (DM) is a disease that can be identified by high levels of blood glucose. Garcinia plants have been widely used for many traditional medicines as antioxidant, anticancer, antidiabetics, and antiinflammation. The antioxidant and antidiabetic activities of (Garcinia picrorrhiza Miq.) or sesoot fruit extract were evaluated in this study and compared with xanthone. The antioxidant and antidiabetic of ethanolic ripe sesoot (G. picrorrhiza Miq.) fruit extract (GpKar) was evaluated by 2,2-Azinobis 3-ethyl benzothiazoline 6-sulfonic acid $\left(\mathrm{ABTS}^{\circ+}\right)$ reducing activity, $\alpha$ Glucosidase, $\beta$-Glucosidase, and $\alpha$-amylase inhibitor activity. GpKar showed higher ABTS ${ }^{\bullet+}$-reducing activity $\left(\mathrm{IC}_{50}=49.30 \mu \mathrm{g} / \mathrm{mL}\right)$ than xanthone $\left(\mathrm{IC}_{50}=404.30 \mu \mathrm{g} / \mathrm{mL}\right)$. GpKar showed $\mathrm{IC}_{50}=109.32$ $\mu \mathrm{g} / \mathrm{mL}$ for $\alpha$-glucosidase inhibitory activity, while xanthones had a better activity $\left(\mathrm{IC}_{50}=33.97\right.$ $\mu \mathrm{g} / \mathrm{mL})$. GpKar also showed lower $\alpha$-amylase inhibitory activity and $\beta$-Glucosidase $\left(\mathrm{IC}_{50}=126.01\right.$ and $9432.09 \mu \mathrm{g} / \mathrm{mL}$ ) compared to xanthone $\left(\mathrm{IC}_{50}=44.32\right.$ and $405.03 \mu \mathrm{g} / \mathrm{mL}$, respectively). The compounds of GpKar are proven to have antioxidant and antidiabetic activities. Therefore, it will be industrially relevant to develop a natural medicine for decreasing DM risk, thus evaluating the antioxidant and antidiabetic effect of G. picrorrhiza by a pre-clinic study is needed.
\end{abstract}

Keywords: antidiabetic, antioxidant, Garcinia picrorrhiza, xanthone

\footnotetext{
*Corresponding author:

Sri Utami

Faculty of Medicine, YARSI University

Jl. Letjend Suprapto, Cempaka Putih, Jakarta Pusat 10510, Indonesia

Email: uutsuyono@yahoo.com
} 


\section{INTRODUCTION}

In 2019, there are about 463 millions people around the world have been diagnosed with diabetes. Moreover, the International Diabetes Federation (IDF) said that diabetes cases are anticipated to grow higher up to 700 millions by 2040 (Pasupuleti et al., 2020). Diabetes is a disease stimulated by high levels of blood glucose (hyperglycemia). Hyperglycemia is a condition in which insulin secretion and/or insulin action experiences some defects (American Diabetes Association, 2013). Diabetes is divided into two types and Type 2 diabetes mellitus (T2DM) can lead to various illnesses and premature death (Pasupuleti et al., 2020). Defect of insulin action and production leads to long-term health problems. In addition to insulin, defects of carbohydrates, lipids, proteins metabolisms also play a role in health problems (American Diabetes Association, 2013). $\alpha$-amylase and $\alpha$-glucosidase are enzymes that stimulate the starch breakdown which is the main source of increased blood sugar levels. Blood glucose levels can be decreased by inhibiting the enzymes and it is an essential strategy in diabetes (Lordan et al., 2013; Widowati et al., 2018).

Diabetes can cause activation of several pathological diseases, chronic hyperglycemia, and free radical generation (Yaribeygi et al., 2019). Free radicals can be neutralized by electron donation from antioxidants. Catalase (CAT), glutathione peroxidase (GPX), superoxide dismutase (SOD) are some antioxidants that counter the deleterious effect of free radicals. These antioxidants are produced in the body or provided through the diet. Furthermore, traditional medicinal plants also have antioxidants (Kumar et al., 2021). Antioxidant plays a protective role in diabetic pathologies and cardiovascular disease.

Garcinia is one of the Clusiaceae family which is native to Asia, Australia, and tropical regions. Garcinia fruit is a nutrient-rich source, minerals, vitamins, and dietary fiber. In several studies, Garcinia plants have been widely used as a traditional natural medicine for antioxidant, anticancer, antidiabetic, and antiinflammation, due to their good source of bioactive compounds (Aisha et al., 2013; Murthy et al., 2019). G. picrrorhiza Miq. grows in tropical to temperate climates and in the original region known as sesoot (Utami et al., 2017). It contains bioactive compounds including xanthones, benzophenones, hydroxycitric acid, and anthocyanins (Espirito Santo et al., 2020). Xanthones are one of the compounds highly found in natural sources, including plants, fungi, ferns, and lichens. Xanthones could be found in several plant families, including Garcinia. Their pharmacological properties have raised a great interest (Negi et al., 2013) and xanthones themselves are polyphenolic compounds that have been widely used in the treatment of DM (Putri, 2015).

Based on the previous study, the extract of G. picrorrhiza Miq. has antioxidant activity and anticholinesterase activity which is potentially used to decrease Alzheimer's disease progression (Utami et al., 2017). Another study related to the Garcinias reported that extract of G. mangostana L. has antidiabetic activity by decreasing cholesterol levels and lipidic peroxidation (Husen et al, 2017); however, the effect of G. picrorrhiza Miq has not been much reported. The genus Garcinia has more than fifty species. However, G. picrorrhiza Miq. is one of the species which is rarely studied. Based on these facts, more comprehensive studies are needed to investigate another bioactivity on $G$. picrorrhiza Miq. extract. The potential of ripe fruit G. picrorrhiza Miq. for DM can be investigated by evaluating the antioxidant activity with the $\mathrm{ABTS}^{++}$method, while the antidiabetic activity was evaluated by $\alpha$-glucosidase, $\alpha$-amylase, and $\beta$-Glucosidase assay.

\section{MATERIALS AND METHOD \\ Material}

Ripe fruits of G. picrorrhiza Miq. were harvested from Bogor Botanical Garden and identified in the herbarium of the School of Life Science and Technology, Bandung Institute of Technology, West Java, Indonesia. The enzymes were $\alpha$-glucosidase from Saccharomyces sp. (Sigma Aldrich G5003), $\beta$-Glucosidase (Sigma-Aldrich G4511), and $\alpha$-amylase enzyme (Sigma Aldrich A7595). $p$ nitrophenyl $\alpha$-D-glucopyranoside (Sigma Aldrich N1377), $p$-nitrophenyl- $\beta$-D-glycopyranoside 
(Sigma-Aldrich N7006). ABTS ${ }^{\cdot+}$ (Sigma Aldrich, A1888). Pure xanthone (Sigma Aldrich X0626) was used in this experiment as a standard compound.

\section{Method}

\section{Preparation of G. picrorrhiza extract}

Ripe fruits of G. picrorrhiza Miq. (1330 g) were ground and immersed in ethanol $70 \%$ for 24 hours. The extraction was carried out twice. This procedure was redone until the colorless filtrate was obtained. The collected filtrates were subsequently evaporated at $40^{\circ} \mathrm{C}$ using a rotatory evaporator, and the extract (GpKar) was kept at $-20^{\circ} \mathrm{C}$ (Prahastuti et al., 2020; Rusmana et al., 2017; Widowati et al., 2016, 2018).

\section{$\mathrm{ABTS}^{\circ+}$ reducing-activity}

The $\mathrm{ABTS}^{\circ+}$ radical $\left(\mathrm{ABTS}^{\cdot+}\right.$ ) has a bluish-green color (More and Makola, 2020) and absorbs at $743 \mathrm{~nm}$. The color was formed when an electron loses because of the nitrogen atom of ABTS ${ }^{*+}$. $\mathrm{ABTS}^{*+}$ itself can be oxidized using potassium persulfate or manganese dioxide (Xiao et al., 2020). Then, $14 \mathrm{mM} \mathrm{ABTS}^{+}$was added into $4.9 \mathrm{mM}$ potassium persulfate to obtain $7 \mathrm{mM} \mathrm{ABTS}^{\circ+}$ in 2.45 $\mathrm{mM}$ potassium persulfate. It was then incubated for 16 hours at room temperature and dark conditions. After that, 5.5 mM PBS (pH 7.4) was added to dilute the ABTS ${ }^{\circ+}$ solution, and the absorbance at 745 $\mathrm{nm}$ using a microreader was measured. $198 \mu \mathrm{L}$ of $\mathrm{ABTS}^{\cdot+}$ solution was added with $2 \mu \mathrm{L}$ of GpKar, xanthones in various concentration $(3.13,6.25,12.5,25,50$, and $100 \mu \mathrm{g} / \mathrm{mL})$. The mixture was kept for 6 minutes at $30^{\circ} \mathrm{C}$ while the absorbance was measured at $745 \mathrm{~nm}$ using Multiscan ${ }^{\mathrm{TM}} \mathrm{GO}$ Microplate Spectrophotometer, Thermo Scientific (Prahastuti et al., 2020). The ABTS ${ }^{\circ+}$ reducing activity $(\%)$ was then determined as median inhibitory concentration $\left(\mathrm{IC}_{50}\right)$ (Prahastuti et al., 2020; Widowati et al., 2016, 2018).

\section{$\alpha$-Glucosidase inhibitory activity assay}

The activity of $\alpha$-glucosidase inhibitory was evaluated with a method taken from the previous study (Gondokesumo et al., 2017; Widowati et al., 2018) with certain modifications. The solution of the $\alpha$-glucosidase enzyme was produced from $1 \mathrm{mg}$ of $\alpha$-glucosidase from Saccharomyces sp. (Sigma Aldrich G5003), diluted in $100 \mathrm{~mL}$ phosphate buffer ( $\mathrm{pH}$ 7.0) that contained $200 \mathrm{mg}$ bovine serum albumin (BSA). The reaction mixture contained $20 \mathrm{mM} p$-nitrophenyl $\alpha$-D-glucopyranoside (Sigma Aldrich N1377), $45 \mu \mathrm{L}$ phosphate buffer, and $5 \mu \mathrm{L}$ of GpKar, xanthone $(7.81,15.63,31.25,62.5,125$, and $250 \mu \mathrm{g} / \mathrm{mL})$. After the reaction mix was homogenized, $25 \mu \mathrm{L} \alpha$-glucosidase was added before incubation $\left(37^{\circ} \mathrm{C}\right.$ in 30 minutes). $\mathrm{Na}_{2} \mathrm{CO}_{3}$ was added after the incubation. The $\alpha$-glucosidase will hydrolyze the $p$-nitrophenyl- $\alpha$-D-glucopyranoside to glucose and $p$-nitrophenol (yellow color) (Widowati et al., 2018). The released p-nitrophenol was then determined using a microplate reader at $400 \mathrm{~nm}$.

Formula 1 was used to calculate $\alpha$-glucosidase assay as below:

$$
\text { Inhibition }(\%)=\frac{C-S \times 100}{c}
$$

Where $\mathrm{C}=$ absorbance value of the negative control

$\mathrm{S}=$ absorbance value of the sample

\section{$\beta$-Glucosidase inhibitory activity assay}

The activity of $\beta$-Glucosidase inhibitory was evaluated with a method taken from the previous study (Gondokesumo et al., 2017; Widowati et al., 2015) with certain modifications. The solution of the $\beta$-Glucosidase enzyme was produced from $1 \mathrm{mg}$ of $\beta$-Glucosidase (Sigma Aldrich G4511), diluted in $100 \mathrm{~mL}$ phosphate buffer ( $\mathrm{pH}$ 7.0) that contained $200 \mathrm{mg}$ BSA. The reaction mixture contained 200 $\mathrm{mM} p$-nitrophenyl- $\beta$-D-glycopyranoside (Sigma Aldrich N7006), 990 $\mu \mathrm{L}$ of $100 \mathrm{mM}$ phosphate buffer 
(pH 7.0), and $10 \mu \mathrm{L}$ of GpKar, and xanthone (7.81, 15.63, 31.25, 62.5, 125, and $250 \mu \mathrm{g} / \mathrm{mL}$ ). For 5 minutes, the reaction mixture was kept at $37^{\circ} \mathrm{C}$, and $500 \mu \mathrm{L}$ of enzyme mixture was added before the second incubation $\left(15\right.$ minutes at $\left.37^{\circ} \mathrm{C}\right)$. The reaction was then ended by supplementation of $200 \mu \mathrm{L}$ $\mathrm{Na}_{2} \mathrm{CO}_{3}(200 \mathrm{mM})$. The $\beta$-Glucosidase hydrolyzed the $p$-nitrophenyl- $\beta$-D-glucopyranoside, and the product was measured at $405 \mathrm{~nm}$ (Gondokesumo et al., 2017; Widowati et al., 2018).

A microplate reader was used to calculate the absorbance at $405 \mathrm{~nm}$ while the inhibition of $\beta$ Glucosidase was evaluated according to formula 2:

$$
\text { Inhibition }(\%)=\frac{\mathrm{C}-\mathrm{Sx} 100}{\mathrm{c}}
$$

Where $\mathrm{C}=$ absorbance value of the negative control

$\mathrm{S}=$ absorbance value of the sample

\section{$\alpha$-amylase inhibitory activity assay}

The assay of $\alpha$-amylase inhibitory activity was done according to the breakdown of the substrate to generate a colored product and the absorbance was measured over a certain period (Utami et al., 2019; Widowati et al., 2015, 2018). For this assay, dimethyl sulfoxide (DMSO) was used as the blank, $30 \mu \mathrm{L}$ of GpKar, xanthone $(20.83,41.67,83.33,166.67,333.33$, and $666.67 \mu \mathrm{g} / \mathrm{mL}$ ) and $10 \mu \mathrm{L}$ of $\alpha-$ amylase enzyme 250 units/g (Sigma Aldrich 7595) were put into the well. The reaction mixture was then incubated for 10 minutes at $37^{\circ} \mathrm{C}$. For the treatment group, $40 \mu \mathrm{L}$ starch solution was added after incubation while for the control group $40 \mu \mathrm{L}$ phosphate buffers were supplemented. The reaction mixture was again kept for another 15 minutes at $37^{\circ} \mathrm{C}$. The $100 \mu \mathrm{L}$ acidic iodine solution (except black) was also added to terminate the enzymatic reaction after incubation. Using a microplate reader, the absorbance was then measured at $565 \mathrm{~nm}$ (Utami et al., 2019; Widowati et al., 2018). Formula 3 was used to calculate $\alpha$-amylase assay, seen as below:

$$
\text { Inhibition }(\%)=\frac{\mathrm{C}-\mathrm{S} \times 100}{\mathrm{c}}
$$

Where $\mathrm{C}=$ absorbance value of the negative control

$\mathrm{S}=$ absorbance value of the sample

\section{Data Analysis}

All data measurements were done three times. Data are shown as means \pm standard deviation. In this study, the statistical analysis was performed using the SPSS Statistics 20.0 computer program. The analysis used the One Way ANOVA, followed by Tukey's HSD Post Hoc Test. The significance value was determined with a $p$-value of $\leq 0.05$.

\section{RESULT AND DISCUSSION}

Sesoot fruit is one of those natives to Asia and Africa which contains many bioactive compounds including xanthones, flavonoids, triterpenoids, and benzophenones (Gutierrez-Orozco and Failla, 2013). Xanthones are polyphenol groups commonly found in mangosteen. Xanthones contain $\alpha$-mangostin, $\gamma$-mangostin, and another minor compound (Mohammad et al., 2019). Xanthones from Garcinia fruit were known to exhibit pharmacologic properties such as antioxidant (Gondokesumo et al., 2019), antidiabetic (Ewenighi et al., 2015), and anti-inflammatory (Mohan et al., 2018). The $\mathrm{ABTS}^{++}$-reducing activity of GpKar and xanthone is shown in Figure. 1, and the $\mathrm{IC}_{50}$ of samples in $\mathrm{ABTS}^{++}$-reducing activity are shown in Table 1. 


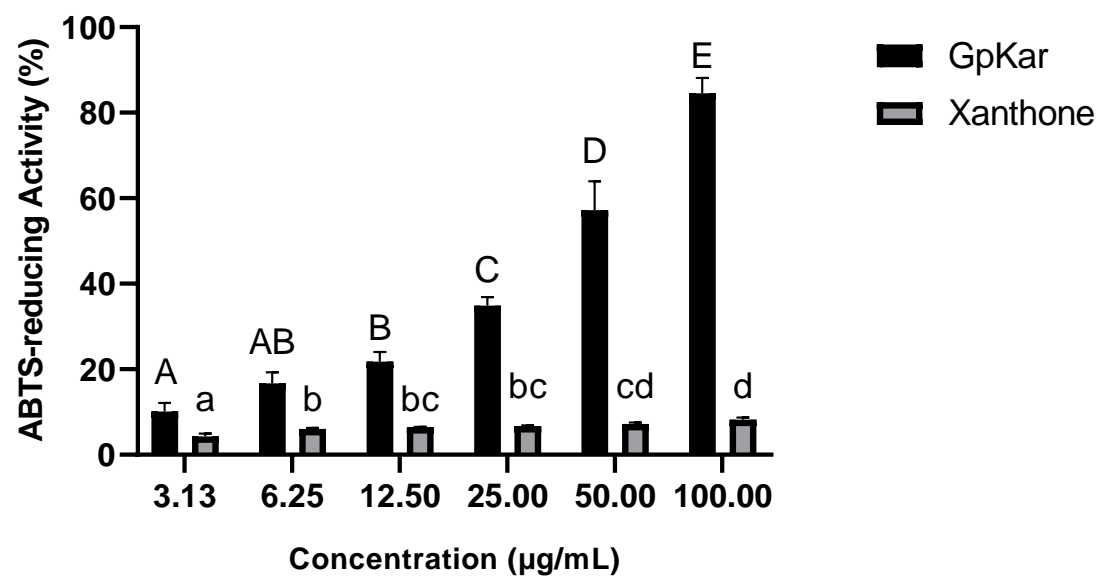

Figure 1. The ABTS $\bullet++$-reducing activity of ethanolic extract of ripe sesoot (G. picrorrhiza Miq.) fruit extract (GpKar) and xanthone. The data are explained as means \pm standard deviation with different letters $(\mathrm{A}, \mathrm{AB}, \mathrm{B}, \mathrm{C}, \mathrm{D}$, and $\mathrm{E})$ for GpKars and different letters (a, b, bc, cd, and d) for xanthone, representing significant differences in Tukey HSD post hoc with $p$ value $\leq 0.05$

Table 1. The $\mathrm{IC}_{50}$ value of $\mathrm{ABTS} \bullet+\bullet+-$ reducing activity of ethanolic extract of ripe sesoot (G. picrorrhiza Miq.) fruit extract (GpKar) and Xanthone

\begin{tabular}{cc}
\hline Sample & IC $_{\mathbf{5 0}}(\boldsymbol{\mu} \mathbf{g} / \mathbf{m L})$ \\
\hline GpKar & 49.30 \\
Xanthone & 404.30 \\
\hline
\end{tabular}

Based on Figure 1, both GpKar and xanthone showed an $\mathrm{ABTS}^{\cdot+}$ reducing activity percentage which depended on the concentration-manner. The higher concentration of the sample shows the higher $\mathrm{ABTS}^{\cdot+}$ reducing activity. Therefore, as seen in Table 1 , GpKar was shown to have a lower $\mathrm{IC}_{50}$ value at $49.30 \mu \mathrm{g} / \mathrm{mL}$ than xanthone at $404.30 \mu \mathrm{g} / \mathrm{mL}$. The $\mathrm{IC}_{50}$ is the the sample concentration to collect $50 \%$ of the free radical. The lower the $\mathrm{IC}_{50}$ value indicates the higher antioxidant activity, and GpKar was categorized highly-active antioxidant (Marjoni and Zulfisa, 2017).

This result conforms with the previous study where $\mathrm{ABTS}^{\circ+}$ antioxidant activity of methanolic extract G. talbotii from India had an $\mathrm{IC}_{50}$ value of $40.09 \mu \mathrm{g} / \mathrm{mL}$ (Kureshi et al., 2020) which was in line with its $\mathrm{ABTS}^{*+}$-reducing activity. Meanwhile, our previous study revealed that the $\mathrm{H}_{2} \mathrm{O}_{2}$ inhibitory scavenging activity of GpKar had a higher activity than xanthone (Utami et al., 2017). The high antioxidant activity of GpKar is probably caused by secondary metabolites. The major secondary metabolites in mangosteen are xanthones and more than 68 xanthones derivatives are isolated. The $\alpha$ mangosteen and $\gamma$-mangosteen are the major xanthone derivates that show powerful antioxidant activity (Aizat et al., 2019; Tjahjani and Widowati, 2013).

Plant extracts are commonly used to treat various diseases including diabetes because of their effectiveness, safety, and abundant sources (Taher et al., 2016). The $\alpha$-glucosidase inhibitors delay the digestion as well as the complex carbohydrates absorption to keep blood glucose at lower levels (Nisha, 2017). The $\alpha$-glucosidase and $\beta$-Glucosidase inhibitors are promising therapeutic agents, such as for diabetes (Kumar et al., 2011), breast cancer (Zhou et al., 2017), antitumor (Li et al., 2018), hepatitis B, and human immunodeficiency virus (HIV) (Abid et al., 2016). The result of the $\alpha$ glucosidase inhibitory activity assay of GpKar and xanthone can be seen in Figure 2. Table 2 illustrates the results of the $\alpha$-Glucosidase, $\beta$-Glucosidase, and $\alpha$-amylase inhibitory activity by the $\mathrm{IC}_{50}$ value. 


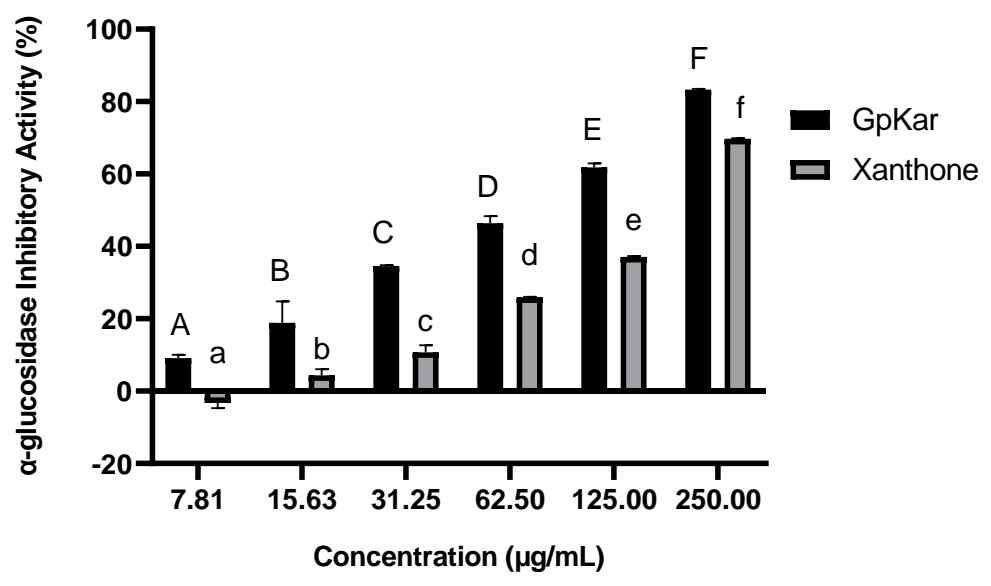

Figure 2. The $\alpha$-Glucosidase inhibitory activity of ethanolic ripe sesoot (G. picrorrhiza Miq.) fruit extract (GpKar) and xanthone. The data are explained as means \pm standard deviation with different letters (A, B, C, D, E, and F) for GpKar and different letters (a, b, c, d, e, and f) for xanthone, representing significant differences in Tukey HSD post hoc with $p$ value $\leq \mathbf{0 . 0 5}$

Table 2. The $\mathrm{IC}_{50}$ value of $\alpha$-glucosidase, $\beta$-Glucosidase, and $\alpha$-amylase inhibitory activities of ethanolic ripe sesoot (G. picrorrhiza Miq.) fruit extract (GpKar) and xanthone

\begin{tabular}{cccc}
\hline Samples & $\begin{array}{c}\boldsymbol{\alpha} \text {-glucosidase inhibitory } \\
\text { activity }\end{array}$ & $\begin{array}{c}\boldsymbol{\beta} \text {-Glucosidase inhibitory } \\
\text { activity }\end{array}$ & $\begin{array}{c}\boldsymbol{\alpha} \text {-amylase } \\
\text { inhibitory activity }\end{array}$ \\
\cline { 2 - 4 } & $\mathbf{I C}_{\mathbf{5 0}}(\boldsymbol{\mu} \mathbf{g} / \mathbf{m L})$ & $\mathbf{I C}_{\mathbf{5 0}}(\boldsymbol{\mu} \mathbf{g} / \mathbf{m L})$ & $\mathbf{I C}_{\mathbf{5 0}}(\boldsymbol{\mu g} / \mathbf{m L})$ \\
\hline GpKar & 109.32 & 126.01 & 9432.09 \\
Xanthone & 33.97 & 44.32 & 405.03 \\
\hline
\end{tabular}

Based on Figure 2, both GpKar and xanthone showed $\alpha$-glucosidase inhibitory activity depending on concentration-manner. Based on Table 2, GpKar showed higher IC $_{50}$ value (109.32 $\mu \mathrm{g} / \mathrm{mL})$ compared to xanthone $(33.97 \mu \mathrm{g} / \mathrm{mL})$; xanthone was categorized highly active (Marjoni and Zulfisa, 2017).

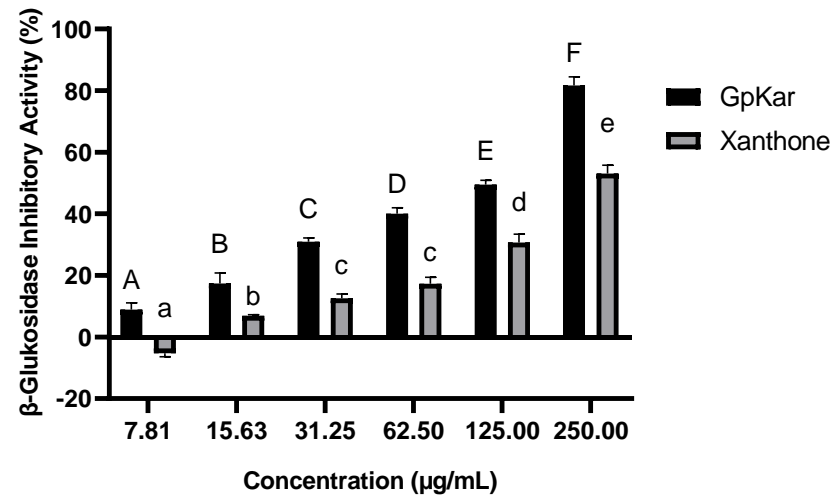

Figure 3. The $\beta$-Glucosidase inhibitory activity of ethanolic ripe sesoot (G. picrorrhiza Miq.) fruit extract (GpKar) and xanthone. The data are explained as means \pm standard deviation with different letters (A, B, C, D, E, and F) for GpKar and different letters (a, b, c, d, and e,) for xanthone, representing significant differences in Tukey HSD post hoc with $p$ value $\leq \mathbf{0 . 0 5}$ 
Based on Figure 3, both GpKar and xanthone showed $\beta$-Glucosidase inhibitory activity depending on concentration-manner. Based on Table 2, GpKar showed a higher $\mathrm{IC}_{50}$ value (126.01 $\mu \mathrm{g} / \mathrm{mL})$ than xanthone $(44.32 \mu \mathrm{g} / \mathrm{mL})$ in inhibition of $\beta$-Glucosidase. This result indicates that GpKar has a lower $\beta$-Glucosidase inhibitory activity than xanthone. Xanthones are categorized as highly active in $\beta$-Glucosidase activity based on these results (Marjoni and Zulfisa, 2017). Xanthones from mangosteen have been proven to suppress glucose absorption and potential compounds for in vitro $\alpha$ glucosidase inhibition (Ryu et al., 2011). The extract of G. mangostana pericarp demonstrated a mild lowering effect on glucose level in normoglycemic animals, which was comparable with glibenclamide (standard drug) (Taher et al., 2016). The antioxidant compounds such as epicatechin and xanthones may play a role in this effect. Therefore, G. mangostana extract is also a strong candidate for DM management (Taher et al., 2016).

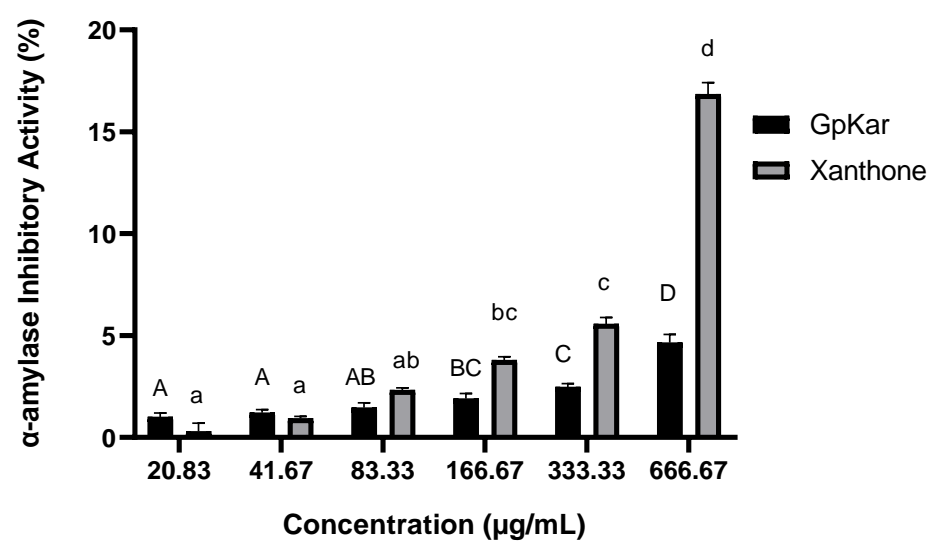

Figure 4. The $\alpha$-amylase inhibitory activity of ethanolic ripe sesoot (G. picrorrhiza Miq.) fruit extract (GpKar) and xanthone. The data are explained as means \pm standard deviation with different letters (A, AB, BC, C, and D) for GpKar and different letters (a, ab, bc, c, and d) for xanthone, representing significant differences in Tukey HSD post hoc with $p$ value $\leq \mathbf{0 . 0 5}$

Based on Figure 4, the $\alpha$-amylase inhibitory activity of GpKar and xanthone showed a concentration dependent-manner. Table 2 shows that the $\mathrm{IC}_{50}$ value of $\mathrm{GpKar}$ was higher $(9432.09$ $\mu \mathrm{g} / \mathrm{mL})$ than xanthone $(405.03 \mu \mathrm{g} / \mathrm{mL})$. Xanthone was categorized weak in $\alpha$-amylase inhibitory activity and GpKar was categorized inactive (Marjoni and Zulfisa, 2017).

There was a report stated that extract of G. mangostana can deaccelerate the absorption of glucose by inhibiting the carbohydrate hydrolyzing enzymes like $\alpha$-amylase (Manaharan et al., 2012). The result in this present study has been in line with the previous study. Inhibition of amylase and glucosidase enzymes is proven to lower the postprandial elevation of blood glucose after a mixed carbohydrate diet (Thamizharasan and Umamaheswa, 2016). Meanwhile, G. kola possesses hypoglycemic properties and significantly lowered blood glucose in alloxan-induced diabetic rats (Ewenighi et al., 2015).

Reactive oxygen species (ROS) and reactive nitrogen species (RNS) are included to free radicals. Unstable electrons in free radicals react with lipids, proteins, and/or DNA resulting in various damages. Oxidative damage happens when free radicals and antioxidant agents are imbalanced (Ayepola et al., 2014). However, oxidative stress affects various diseases such as diabetes, vascular and neural disorders (Pasupuleti et al., 2020). Various mechanisms of oxidative stress play a role in diabetes, including excess oxygen radicals, glycated protein formation, and the glycation of antioxidant enzymes. This will limit the ability of antioxidants to prevent free radicals (Pasupuleti et al., 2020). The previous study showed that various group compounds such as phenolic, flavonoids, anthocyanins, and carotenoids could have a contribution to the antioxidant activity in the extracts of $G$. 
parvifolia fruit (Hassan et al., 2013). Moreover, Hassan stated that the sum up phenolic content strongly correlated with the activity of antioxidant (Hassan et al., 2013). The quality of antioxidant properties relates to various factors, and the major factors that affect the activities are the maturation stage, extraction solvent, and materials preparations (Suttirak and Manurakchinakorn, 2014).

\section{CONCLUSION}

The extract of sesoot fruit has highly active antioxidants while xanthone has weak antioxidant properties. The extract of sesoot has moderate $\alpha$ and $\beta$-Glucosidase inhibition and inactive $\alpha$-amylase inhibition properties. On the other hand, xanthone has highly active $\alpha$ and $\beta$-Glucosidase inhibition and weak $\alpha$-amylase inhibition properties. Further research to develop its activity in antidiabetic prevention by pre-clinic studies is needed.

\section{ACKNOWLEDGEMENT}

This study was supported financially by YARSI University for research grant 2016 . Thanks to research methodology and laboratory facilities supported by Aretha Medika Utama Biomolecular and Biomedical Research Center, Bandung, Indonesia. The authors would also like to thank Ervi Afifah, Seila Arumwardana, Cintani Dewi Wahyuni, Cahyaning Riski Wijayanti, Muhamad Aldi Maulana from Biomolecular and Biomedical Research Center, Aretha Medika Utama for all their help in this project.

\section{REFERENCES}

Abid, S., \& Bnouham, A. B. and M. (2016). Natural alpha-glucosidase inhibitors: therapeutic implication and structure- activity relation ship. Letters in Drug Design \& Discovery. https://doi.org/http://dx.doi.org/10.2174/1570180812666150918193508

Aisha, A., Abu-Salah, K., Ismail, Z., \& Majid, A. (2013). Determination of total xanthones in Garcinia mangostana fruit rind extracts by ultraviolet (UV) spectrophotometry. Journal of Medicinal Plants Research, 7, 29-35

Aizat, W. M., Jamil, I. N., Ahmad-Hashim, F. H., \& Noor, N. M. (2019). Recent updates on metabolite composition and medicinal benefits of mangosteen plant. PeerJ, 7, e6324-e6324. https://doi.org/10.7717/peerj.6324

Association, A. D. (2013). Diagnosis and classification of diabetes mellitus. Diabetes Care, 36 Suppl 1(Suppl 1), S67-74. https://doi.org/10.2337/dc13-S067

Ayepola, O. R., Brooks, N. L., \& Oguntibeju, O. O. (2014). Oxidative stress and diabetic complications: the role of antioxidant vitamins and flavonoids. Antioxidant-Antidiabetic Agents and Human Health, 923-931

Espirito Santo, B. L. S. do, Santana, L. F., Kato Junior, W. H., de Araújo, F. de O., Bogo, D., Freitas, K. de C., ... Bastos, P. R. H. de O. (2020). Medicinal potential of garcinia species and their compounds. Molecules (Basel, $\quad$ Switzerland), 25(19), 1-30. https://doi.org/10.3390/molecules25194513

Ewenighi, C., Dimkpa, U., Onyeanusi, J., Onoh, L., Onoh, G., \& Ezugwu, U. (2015). Estimation of glucose level and body weight in Alloxan Induced Diabetic Rat treated with Aqueous extract of Garcinia kola Seed. Ulutas Medical Journal, 1, 26-30

Gondokesumo, M. E., Kusuma, H., \& Widowati, W. (2017). \$ $\alpha$ - $\$ \$ \beta \$$-Glucosidase and \$ $\alpha$-Amylase Inhibitory activities of Roselle (Hibiscus sabdariffa L.) ethanol extract

Gondokesumo, M. E., Pardjianto, B., Sumitro, S. B., \& Widowati, W. (2019). Xanthones analysis and antioxidant activity analysis (Applying ESR) of six different maturity levels of Mangosteen rind extract (Garcinia mangostana Linn.). Pharmacognosy Journal, 11(2)

Gutierrez-Orozco, F., \& Failla, M. L. (2013). Biological activities and bioavailability of mangosteen xanthones: a critical review of the current evidence. Nutrients, 5(8), 3163-3183. https://doi.org/10.3390/nu5083163 
Hassan, A., Hawa, S., Fry, J. R., \& Abu Bakar, M. F. (2013). Phytochemicals content, antioxidant activity and acetylcholinesterase inhibition properties of indigenous Garcinia parvifolia fruit. BioMed Research International, 2013, 138950. https://doi.org/10.1155/2013/138950

Husen, S. A., Winarni, D., Khaleyla, F., Kalqutny, S. H., \& Ansori, A. N. M. (2017). Activity assay of mangosteen (Garcinia mangostana L.) pericarp extract for decreasing fasting blood cholesterol level and lipid peroxidation in type-2 diabetic mice. In AIP Conference Proceedings (Vol. 1888, p. 20026). AIP Publishing LLC

Kumar, M., Pratap, V., Nigam, A., Sinha, B., Singh, M., \& Gour, J. (2021). Plants as a source of potential antioxidants and their effective nanoformulations. Journal of Scientific Research, 65, 57-72. https://doi.org/10.37398/JSR.2021.650308

Kumar, S., Narwal, S., Kumar, V., \& Prakash, O. (2011). $\alpha$-glucosidase inhibitors from plants: A natural approach to treat diabetes. Pharmacognosy Reviews, 5(9), 19-29. https://doi.org/10.4103/0973-7847.79096

Kureshi, A., Mirgal, A., Salvi, S., Kumari, P., Singh, R., \& Kumar, S. (2020). Antioxidant activities and phenolic contents of Garcinia talbotii fruit rind. Research Journal of Medicinal Plants, 14, 104-110. https://doi.org/10.3923/rjmp.2020.104.110

Li, Y.-L., Li, Q.-X., Liu, R.-J., \& Shen, X.-Q. (2018). Chinese medicine amygdalin and $\beta$-glucosidase combined with antibody enzymatic prodrug system as a feasible antitumor therapy. Chinese Journal of Integrative Medicine, 24(3), 237-240. https://doi.org/10.1007/s11655-015-2154-X

Lordan, S., Smyth, T. J., Soler-Vila, A., Stanton, C., \& Ross, R. P. (2013). The $\alpha$-amylase and $\alpha-$ glucosidase inhibitory effects of Irish seaweed extracts. Food Chemistry, 141(3), 2170-2176. https://doi.org/10.1016/j.foodchem.2013.04.123

Manaharan, T., Palanisamy, U. D., \& Ming, C. H. (2012). Tropical plant extracts as potential antihyperglycemic agents. Molecules (Basel, Switzerland), 17(5), 5915-5923. https://doi.org/10.3390/molecules17055915

Mohammad, N. A., Abang Zaidel, D. N., Muhamad, I. I., Abdul Hamid, M., Yaakob, H., \& Mohd Jusoh, Y. M. (2019). Optimization of the antioxidant-rich xanthone extract from mangosteen (Garcinia mangostana L.) pericarp via microwave-assisted extraction. Heliyon, 5(10), e02571. https://doi.org/https://doi.org/10.1016/j.heliyon.2019.e02571

Mohan, S., Syam, S., Abdelwahab, S. I., \& Thangavel, N. (2018). An anti-inflammatory molecular mechanism of action of $\alpha$-mangostin, the major xanthone from the pericarp of Garcinia mangostana: an in silico, in vitro and in vivo approach. Food \& Function, 9(7), 3860-3871. https://doi.org/10.1039/c8fo00439k

More, G. K., \& Makola, R. T. (2020). In-vitro analysis of free radical scavenging activities and suppression of LPS-induced ROS production in macrophage cells by Solanum sisymbriifolium extracts. Scientific Reports, 10(1), 6493. https://doi.org/10.1038/s41598-020-63491-w

Murthy, H. N., Dandin, V. S., Dalawai, D., Park, S.-Y., \& Paek, K.-Y. (2019). Bioactive compounds from Garcinia fruits of high economic value for food and health. Bioactive Molecules in Food, Reference Series in Phytochemistry; Merillon, JM, Ramawat, KG, Eds, 1-27

Negi, J. S., Bisht, V. K., Singh, P., Rawat, M. S. M., \& Joshi, G. P. (2013). Naturally occurring xanthones: chemistry and biology. Journal of Applied Chemistry, 2013, 621459. https://doi.org/10.1155/2013/621459

Nisha, J. (2017). Molecular docking analysis of novel alpha-glucosidase enzyme inhibitors from siddha formulation pungampoo chooranam using computer aided drug discovery. International Journal of Current Research In Chemistry And Pharmaceutical Sciences, 4(10), 18-26

Pasupuleti, V. R., Arigela, C. S., Gan, S. H., Salam, S. K. N., Krishnan, K. T., Rahman, N. A., \& Jeffree, M. S. (2020). A review on oxidative stress, diabetic complications, and the roles of honey polyphenols. Oxidative Medicine and Cellular Longevity, 2020, 8878172. https://doi.org/10.1155/2020/8878172

Prahastuti, S., Hidayat, M., Hasiana, S. T., Widowati, W., Widodo, W. S., Handayani, R. A. S., ... Kusuma, H. S. W. (2020). The ethanol extract of the bastard cedar (Guazuma ulmifolia L.) as 
$\begin{array}{llllllll}\text { antioxidants. } & \text { Pharmaciana; } & \text { Vol } & 10, & \text { No } & 1 & \text { (2020), } & 77-88\end{array}$ http://dx.doi.org/10.12928/pharmaciana.v10i1.13636

Putri, I. P. (2015). Effectivity of xanthone of mangosteen (Garcinia mangostana L.) rind as anticancer. Jurnal Majority, 4(1), 33-38.

Marjoni, M.R., \& A, Z. (2017). Antioxidant activity of methanol extract/fractions of senggani leaves (Melastoma candidum D. Don). Pharmaceutica Analytica Acta, 8(8), 1-6. https://doi.org/10.4172/2153-2435.1000557

Rusmana, D., Wahyudianingsih, R., Elisabeth, M., Balqis, B., Maesaroh, M., \& Widowati, W. (2017). Antioxidant activity of Phyllanthus niruri extract, rutin and quercetin. The Indonesian Biomedical Journal, 9(2), 84-90.

Ryu, H. W., Cho, J. K., Curtis-Long, M. J., Yuk, H. J., Kim, Y. S., Jung, S., .. Park, K. H. (2011). $\alpha-$ Glucosidase inhibition and antihyperglycemic activity of prenylated xanthones from Garcinia mangostana. Phytochemistry, 72(17), 2148-2154.

Suttirak, W., \& Manurakchinakorn, S. (2014). In vitro antioxidant properties of mangosteen peel extract. Journal of Food Science and Technology, 51(12), 3546-3558.

Taher, M., Zakaria, T. M. F. S. T., Susanti, D., \& Zakaria, Z. A. (2016). Hypoglycaemic activity of ethanolic extract of Garcinia mangostana Linn. in normoglycaemic and streptozotocin-induced diabetic rats. BMC Complementary and Alternative Medicine, 16(1), 1-12.

Thamizharasan, S., \& Umamaheswari, S, R. H. (2016). a - amylase and a - glucosidase Activity of Mimosa pudica Linn. Flowers. Paripex - Indian Journal of Research, 5(7), 223-224.

Tjahjani, S., \& Widowati, W. (2013). The potency of xanthones as antioxidant and antimalarial, and their synergism with artemisinin in vitro. Journal of the Indonesian Medical Association, 63(3), 95-99.

Utami, S., Adityaningsari, P., Sosiawan, I., Endrini, S., Sachrowardi, Q. R., Laksono, S. P., ... Widowati, W. (2017). Antioxidants and anticholinesterase activities of the characterized ethanolic of ripe sesoot (Garcinia picrorrhiza Miq.) fruit extract (GpKar) and xanthone. Majalah Obat Tradisional, 22(3), 160. https://doi.org/10.22146/mot.31548

Utami, S., Endrini, S., Nafik, S., Lestari, I. M. T., Anindya, D., Bakar, E. A., ... Arumwardana, S. (2019). In vitro antioxidant and anti-obesity activities of Freeze-dried Canarium sp., Averrhoa bilimbi L. and Malus domestica. The Indonesian Biomedical Journal, 11(3), 320-326.

Widowati, W., Fauziah, N., Herdiman, H., Afni, M., Afifah, E., Kusuma, H. S. W., ... Rihibiha, D. D. (2016). Antioxidant and anti aging assays of Oryza sativa extracts, vanillin and coumaric acid. Journal of Natural Remedies, 16(3), 88-99. https://doi.org/10.18311/jnr/2016/7220

Widowati, W., Maesaroh, M., Fauziah, N., pande putu, E., \& Sandra, F. (2015). Free radical Scavenging and Alpha/Beta-glucosidases inhibitory activities of rambutan (Nephelium lappaceum L.) Peel extract. The Indonesian Biomedical Journal, 7, 157. https://doi.org/10.18585/inabj.v7i3.180

Widowati, W., Wargasetia, T., Afifah, E., Mozef, T., Kusuma, H., Nufus, H., ... Rizal, R. (2018). Antioxidant and antidiabetic potential of Curcuma longa and its compounds. Asian Journal of Agriculture and Biology, 6, 149-161.

Xiao, F., Xu, T., Lu, B., \& Liu, R. (2020). Guidelines for antioxidant assays for food components. Food Frontiers, 1(1), 60-69

Yaribeygi, H., Atkin, S. L., \& Sahebkar, A. (2019). A review of the molecular mechanisms of hyperglycemia-induced free radical generation leading to oxidative stress. Journal of Cellular Physiology, 234(2), 1300-1312

Zhou, X., Huang, Z., Yang, H., Jiang, Y., Wei, W., Li, Q., ... Liu, J. (2017). $\beta$-Glucosidase inhibition sensitizes breast cancer to chemotherapy. Biomedicine \& Pharmacotherapy, 91, 504-509. 